\title{
Relasiebegrippe in die lig van die vraag of Einstein in die eerste plek ' $n$ 'relatiwiteitsteorie' ontwikkel het
}

\author{
Author: \\ Danie F.M. Strauss ${ }^{1}$ \\ Affiliation: \\ ${ }^{1}$ Department of Philosophy, \\ University of the Free State, \\ South Africa \\ Correspondence to: \\ Danie Strauss \\ Email: \\ dfms@cknet.co.za \\ Postal address: \\ Capt. Goodman Street 3 \\ Bloemfontein 9310, \\ South Africa \\ Dates: \\ Received: 19 Nov. 2010 \\ Accepted: 04 Apr. 2011 \\ Published: 23 June 2011 \\ How to cite this article: \\ Strauss, D.F.M., 2011, \\ 'Relasiebegrippe in die lig \\ van die vraag of Einstein \\ in die eerste plek 'n \\ 'relatiwiteitsteorie' ontwikkel \\ het', Suid-Afrikaanse Tydskrif \\ vir Natuurwetenskap en \\ Tegnologie 30(1), Art. \#28, \\ 8 pages. doi:10.4102/satnt. \\ v30i1.28
}

C 2011. The Authors. Licensee: OpenJournals Publishing. This work is licensed under the Creative Commons Attribution License.
In die Duitse literatuur word daar dikwels van 'ideë-geskiedenis' gepraat. Dit is daarop gemik om die historiese agtergrond van die keuse en die gebruik van bepaalde terme te verduidelik. In hierdie studie word so 'n 'idee-historiese' benadering gevolg met die eintlike intern-vakwetenskaplike status en strekking van Einstein se bekende teorie (uit die jare 1905 en 1916). Sedert die vroeg-moderne tyd is die klem in die natuurwetenskappe van 'dingebegrippe' na 'relasiebegrippe' verskuif, terwyl verdere ontwikkelinge die invloed van die historistiese geestesklimaat van die 19de en vroeg-20ste eeu sou weerspieël. Daar word ook aandag gegee aan die wyse waarop Einstein se relatiwiteitsteorie die positiewe element in die verskuiwing na relasiebegrippe ontgin, hoewel die algemeen-bekende naamgewing van sy teorie (bewustelik of onbewustelik) die historistiese Zeitgeist [tydgees] aan die begin van die 20ste eeu tot ' $n$ mate weerspieël. Tog blyk dit dat hy self die benoeming van die teorie bevraagteken het in die lig van die inherent-teenstrydige aard van die historisme. Hy het immers besef dat konstansie verandering veronderstel; verandering moet, of kan, dus nie beklemtoon word ten koste van konstansie nie. Terselfdertyd omvat die spesiale en algemene dele van sy teorie ' $n$ insig in die onderskeiding tussen die kinematiese en fisiese aspekte van die werklikheid asook die funderende rol van uniforme beweging ten opsigte van fisiese verandering. Beide hierdie aspekte belig die relasiebegrippe waarvan Einstein gebruik maak, veral soos dit uitgedruk word in sy klem op energie-konstansie, waar die term energie die unieke sin van die fisiese aspek reflekteer en konstansie dié van die kinematiese aspek. Die beredenering van die hele artikel verwys deurgaans terug daarna dat konstansie die basis van dinamiek en verandering vorm en dat Einstein derhalwe in die eerste plek nie ' $\mathrm{n}$ teorie van relatiwiteit ontwikkel het nie, maar 'n teorie van konstansie. Sy teorie toon dus ook aan dat die historistiese gees van sy tyd inherent problematies is, want historisme beklemtoon verandering ten koste van konstansie: dit alles ten spyte van die feit dat die gees van sy tyd waarskynlik 'n rol gespeel het die in benoeming van sy teorie, naamlik as ' $n$ relatiwiteitsteorie.

In the German literature the history of 'ideas' is often mentioned. Its aim is to account for the historical background of the choice and use of certain terms. In this instance such an 'idea-historical' approach is connected to the truly intrinsic scientific status and intention of the well-known theory of Einstein (from the years 1905 and 1916). The emphasis within the natural sciences switched since the early modern era from thing-concepts to relation-concepts, whilst the forthcoming developments eventually revealed the influence of the historicistic spiritual climate of the 19th and the early 20th century. It was also investigated in which way Einstein's theory of relativity explored the positive element in the shift from thing-concepts to relation-concepts even though the generally known designation of his theory (consciously or subconsciously) reflected something of the historicistic Zeitgeist [spirit of the time] at beginning of the 20th century. Nonetheless it would turn out that he was not convinced of the intrinsic antinomic nature of historicism, precisely because he realised that constancy underlies change and for that reason it cannot be emphasised at the cost of constancy. At the same time the special and general parts of his theory embody an insight into the distinct nature of the kinematic and physical aspects of reality and of the foundational role of the kinematic in respect of the physical aspect. Both these aspects underly the relation-concepts employed by Einstein, particularly as they are embodied in his emphasis on energy-constancy, where the term energy reflects the unique meaning of the physical aspect and constancy that of the kinematic aspect. The argumentation of the entire article is focused on the insight that constancy forms the basis of dynamics and change and that Einstein consequently did not develop a theory of relativity, but rather a theory of constancy. It follows that his theory at once demonstrates that the historicistic Zeitgeist of his time is intrinsically antinomic in its emphasis on change at the cost of constancy. This, moreover, is true in spite of the fact that the spirit of his time probably played a role in the designation of his theory, namely as a theory of relativity. 


\section{Inleiding Tussen relatiwiteit en absoluutheid}

Gegewe die welbekende aanduiding van Einstein se teorie as 'n relatiwiteitsteorie, word studente in die fisika asook die algemene publiek genoop om terselfdertyd te dink aan die teenstelling tussen relatiwiteit en absoluutheid. Hierdie teenstelling lig op sy beurt ander relevante konnotasies uit. Een daarvan is die besef dat alles in die realiteit onderling verbind is, dit wil sê, gerelateerd is of in 'n wederkerige samehang bestaan. ' $n$ Alternatiewe uitdrukking van hierdie gedagte is dat alles in relasie met alles anders staan. Die gedagte dat alles onderling verbind is, word onder meer beklemtoon deur die Duitse fisikus, C.F. Von Weiszäcker, waar hy opmerk: 'Alles hang met alles saam [sic]' (Von Weizsäcker 1993:134). Dit impliseer dat niks in die realiteit absoluut is nie. Skepsel-wees impliseer relatiwiteit, maar nie relativisme nie. Die historisme meen egter dat alles verander, vergetende dat verandering (soos ons hieronder sal redeneer) altyd konstansie veronderstel.

Die erkenning van geïntegreerdheid impliseer dat daar samehange of relasies tussen dinge bestaan en hierdie relasies word met behulp van relasiebegrippe of funksiebegrippe verantwoord. Sulke relasiebegrippe of funksiebegrippe moet egter van konkrete dingebegrippe onderskei word. Die ongespesifiseerde universaliteit van die bestaanswyses of funksies van die werklikheid, wat met betrekking tot die moderne fisika en Einstein se relatiwiteitsteorie veral die getalsaspek, ruimte-aspek, bewegingsaspek en die fisiese aspek aan die orde stel, is hier van belang. Galileo het reeds die eerste drie beklemtoon deur getal (telbaarheid), ruimte (vorm, grootte, lengte) en beweeglikheid (die kinematiese), as primêre kwaliteite van materie uit te lig (vgl. Hucklenbroich 1980:291).

Bedink hierby dat alle moontlike fisiese entiteite (dinge), vanaf elementêre deeltjies (soos kwarke), atome, molekule, makromolekule tot by makrosisteme, hoeseer hulle ookal onderling mag verskil, terselfdertyd aan die hoofwette van die fisika onderworpe is (soos die 'Wet van die behoud van energie' en die 'Wet van toename in entropie' in geslote sisteme). Die universaliteit van die fisiese aspek fundeer die relasie of samehang wat tussen uiteenlopende fisiese entiteite bestaan. Von Weizsäcker het duidelik ingesien dat die kwantum-teorie byvoorbeeld ' $n$ modaal-universele teorie is omdat dit vir alle entiteite geldig is (Von Weizsäcker 1993:128). Dit sal blyk dat die spesiale relatiwiteitsteorie 'n kinematiese teorie en die algemene relatiwiteitsteorie ' $\mathrm{n}$ fisiese teorie is.

Benewens funksiebegrippe soos massa, veld, beweging of ernergie-werking, gebruik die moderne fisika egter ook tipiese dingebegrippe, soos in die bogemelde hiërargie, vanaf elementêre deeltjies tot by makrosisteme. Dit beteken dat daar ook onderskei moet word tussen modale wette en tipiese wette (funksie-wette en dinge-wette) omdat tipiese wette nie uit modale wette afgelei kan word nie: iets wat die fisikus Von Weizsäcker ook duidelik ingesien het, want hy verduidelik dat die tipiese entiteite van ons ervaring nie uit die universele reikwydte van die kwantum-teorie afgelei kan word nie. Daarmee verwys hy na dít wat ons as tipiese wette sien (Von Weizsäcker 1993:129). Nog 'n fisikus, Stafleu, belig die onderskeiding tussen modale en tipiese wette met verwysing na modale wette (soos die Wet van traagheid) wat vir alle soorte subjekte geld en tipe-wette wat slegs vir 'n beperkte klas van dinge geld (soos die Coulomb wet wat slegs vir fisiese entiteite met ' $n$ lading geldig is of die Pauli-beginsel wat slegs geld vir fermione) (Stafleu 1980:11; vgl. bladsy 6).

Die realiteit van 'modes of being' [bestaanswyses] stel ons in staat om vakwetenskappe in die sin van 'aspek-dissiplines' te onderken, want in alle egte vakwetenskappe gaan dit steeds om die volle realiteit wat van vanuit die gesigshoek van een of ander modale aspek ondersoek word. Diemer praat tereg van 'n Aspektediziplin [Aspek-dissipline] (Diemer 1970:219).

Terselfdertyd suggereer dit dat die ander pool van die teenstelling ook aangedui sou kon word met die idee van onafhanklikheid, selfstandigheid, onverbondenheid of selfgenoegsaamheid.

Uit die Griekse en Middeleeuse filosofie is een of ander oorsprongsinstansie, of tewens God self, vanuit hierdie hoek getipeer. In teenstelling met die betreklikheid (relatiwiteit) van alles in die realiteit is God as absoluut gesien. Natuurwetenskaplikes en fisici in die besonder is vertroud met hierdie term aangesien Newton self onbeskaamd met die idees van 'n absolute ruimte (gewaardeer as die sensorium Dei [die waarnemingsruimte van God]) en 'n absolute tyd gewerk het.

Tradisioneel is die 'absolute' dus verbind aan die idee van God. Talle moderne natuurwetenskaplikes het hulle egter skynbaar van 'n Gods-idee bevry. In die jongste boek van Stephen Hawking, The Grand Design (The Economist 2010) argumenteer hy dat die fisiese heelal onafhanklik deur die gravitasiewet uit niks geskep kan word (Hawking et al. 2010). Sonder om die aard van die swaartekragwet te verantwoord is die onderliggende aanname dat die heelal sy ontstaan te danke het aan 'n fisiese oorsprong wat beliggaam word in hierdie fisiese wet. Die geponeerde 'niks' ontpop dan skielik as ' $n$ 'iets', naamlik die 'self-skeppende' fisiese oorsprong van alles. Gravitasie word tegelyk verhef tot oorsprongsbeginsel. Ironies genoeg stel die eerste hoofwet van die fisika dit dat energie nie geskep of vernietig kan word nie, regstreeks in stryd met die idee dat die gravitasiewet die heelal uit niks sal skep nie. Max Planck stel kategories dat alles in fisika onderhewig is aan die Wet van 'energie-behoud'(Planck 1915:95).

Hierdie redenering beliggaam presies wat Clouser aandui as 'n religieuse oortuiging. "n Religieuse oortuiging is 'n vertroue in iets as goddelik per se, ongeag van hoe daardie 'iets' verder beskryf word, en waar "goddelik per se" dui op 'n onvoorwaardelike en onafhanklike bestaan' (Clouser 2005:23). [Let daarop dat Clouser onderskei tussen godsdiens in enegere sin, as vertakking van die mens se lewe, en religie wat op die wortel-verbintenis van mens-wees dui en daarom 
aan alle vertakkinge van die mens se lewe ten grondslap lê, ook aan die nie-godsdienstige fasette.] Clouser vermeld die voorbeeld van filosofiese materialisme wat glo 'dat realiteit oplaas fisies van aard is sodat alles óf uit materie bestaan óf afhanklik is van materie' (Clouser 2005:35). Paul Ziff het per geleentheid opgemerk dat hy 'n materialis is 'nie oor die argumente nie. Ek dink net dat realiteit onweerstaanbaar fisies vir my lyk' (Clouser 2005:38). Die begrip massa (met 'n massapunt as die eenvoudigste subjek in die klassieke meganika) verwys terug na die Middeleeuse denke waar reeds na ' $n$ hoeveelheid materie verwys is as quantitas materiae [hoeveelheid materie] (Maier 1949:144). Hieruit blyk dit dat getal 'n sleutelrol speel in die begrip van materie, want dit korreleer met ' $n$ fisiese kwantiteit. Hierdie begrip hou uiteraard ook verband met die aksie-kapasiteit wat inherent aan 'n bewegende liggaam is, wat vanuit die perspektief van die kinematiese aspek as kinetiese energie aangedui word (Maier 1949:142). Die gravitasiewet veronderstel ook die ruimteaspek want dit gaan oor die afstand tussen twee massapunte. Die klassieke formulering van die 'Wet van Swaartekrag' kan derhalwe nie losgemaak word van die bogemelde vier mees basiese aspekte van die heelal nie, by name die getalsaspek, die ruimte-aspek, die bewegingsaspek en die fisiese aspek. Let daarop dat $F$ die grootte van die aantrekkingskrag tussen twee massapunte $\left(m_{1}\right.$ en $\left.m_{2}\right)$ is, dat $G$ die gravitasie-konstante is, en dat $r$ die afstand tussen die twee massapunte is. Die krag waarmee $m_{1}$ en $m_{2}$ mekaar aantrek is direk eweredig aan die produk van hul massa en omgekeerd eweredig aan die kwadraat van die afstand tussen hulle:

$F=G \frac{m_{1} m_{2}}{r^{2}}$

[Verg. 1]

In die lig van die voorafgaande kan die aard van 'n fisiese wet (soos die gravitasiewet), nooit suiwer (of eksklusief) fisies verstaan word nie. Die sin van so 'n wet hang onlosmaaklik saam met die ander gemelde aspekte van die realiteit asook met die korrelaat daarvan, naamlik dit wat daaraan onderworpe is, dit waarvoor die wet geld (vgl. ook hiermee die kritiese artikel in The Economist 2010).

Selfs die geskiedenis van die materie-begrip weerspieël ook die appèl van die aspekte van getal, ruimte, beweging en die fisiese, soos bevestig deur die twee opponerende sienings en probleme wat Stegmüller uitlig, by name die spanning tussen die atomistiese en die kontinuitteitsopvatting en die vraag na die skynbare onvernietigbaarheid van materie aan die een kant (materie kan nie geskep of vernietig word nie), en die skynbare radikale veranderlikheid daarvan aan die ander kant (Stegmüller 1987:91). Die idee van konstantheid vind sy 'tuiste' in die kinematiese aspek (van 'eenparige [uniforme of konstante] beweging'), wat die grondslag is van alle verandering. Dit is egter nodig om meer te sê oor die insig dat verandering slegs bepaal kan word op die basis van duursaamheid of konstansie.

Teenoor Herakleitos se sentraalstelling van verandering was Plato die eerste filosoof wat ingesien het dat verandering duursaamheid of konstansie veronderstel. Hy voer tewens aan dat as alles voortdurend verander ons nie in staat sal wees om kennis van enigiets te bekom nie, want die volgende oomblik sou dit verander. Gevolglik ontwerp Plato sy, weliswaar spekulatiewe, teorie van bosinnelike wesensvorme (idees) wat altyd dieselfde bly (konstant is) (vgl. Plato se dialoog Kratylos 439c-440a). Gestroop van die spekulatiewe agtergrond van sy ideëleer het Plato hiermee die insig verwerf dat verandering slegs op die basis van konstansie vasgestel kan word. Ook ons alledaagse ervaring van die veranderlikheid van dinge berus op die relatiewe duursaamheid of konstansie daarvan. Alvorens aangetoon sal word dat die kern van Einstein se relatiwiteitsteorie hierdie insig veronderstel, is dit nodig om ' $n$ opmerking te maak oor die Groot Knal-teorie en oor die prominensie van relasiebegrippe wat sedert die Renaissance die toneel van (veral) die natuurwetenskappe betree het.

Hedendaagse Groot Knal-fisici gaan ook van die standpunt uit dat daar ' $n$ singulariteit bestaan wat as 'oorspronklike moment' die ontstaan van die heelal kan verduidelik. Hoewel ruimtelike en tydelike eienskappe negeer (ontken) word, word vanuit 'n oorsprongsituasie vertrek waarin hitte en digtheid ' $\mathrm{n}$ deurslaggewende rol speel. Hiermee word hierdie fisiese (!) singulariteit op dieselfde wyse behandel as waarop vroeg-Middeleeuse denkers hul negatiewe teologie ontwikkel het met die aanname dat ons nie positief kan sê wat God is nie, maar slegs wat God nie is nie. Ten spyte van hierdie gepretendeerde negasie van alle begripsbepalinge (vergelyk Plato se dialoog Parmenides-Plato1973) het elke negatiewe teologie steeds een of ander positiewe aanduiding gebruik. Ook van die Groot Knal-teoretici slaag nie daarin om los te kom van sommige positiewe aanduidinge nie, soos digtheid en temperatuur. Bowendien het ' $\mathrm{n}$ groep van 405 fisici 'n paar jaar gelede beswaar gemaak teen die wyse waarop hoofstroom-fisici ander fisici, wat nie die standaard Groot Knal-teorie aanvaar nie, onregverdig behandel wat betref navorsingsbefondsing, publikasie-geleenthede in vaktydskrifte en posbekleding (Arp et al. 2010).

\section{Materiaal en metodes Dingebegrippe en relasiebegrippe}

In die Griekse en Middeleeuse denke staan die substansiebegrip egter sentraal. Die idee van 'n entiteit as ' $n$ individuele geheel wat op sigself bestaan vorm die kruks van die substansiebegrip. Aristoteles begin sy werk Categoriae met die postulering van 'n volstrek individuele, primêre substansie (proten ousian) (Aristoteles 2001:1 e.v.). In die vroeg-moderne tyd vat Descartes hierdie erfenis soos volg saam: 'By substance we can conceive nothing else than a thing which exists in such a way as to stand in neeed of nothing beyond itself in order to its existence' [Met substansie kan ons ons niks anders voorstel as iets wat niks anders nodig het om te bestaan nie] (Descartes 1965:184).

Waar die substansiebegrip gerig is op dit wat (op sigself) bestaan, die konkrete wat van die dinge, word die moderne era sedert die Renaissance toenemend gekenmerk deur 'n belangstelling in die wyse waarop dinge bestaan, dit wil sê op die hoe daarvan. Hierdeur is die bestaanswyses van 
ons werklikheidservaring op die voorgrond geplaas. Die werking van die dinge, hul funksionering, het gevolglik meer prominensie ontvang as die blote bestaan daarvan. In onderskeiding van die lank oorheersende belangstelling in dingebegrippe, waarin ' $\mathrm{n}$ ondergeskikte posisie toegeken is aan die eienskappe van dergelike dinge, ontmoet ons in hierdie nuwe ontwikkeling sedert die Renaissance die eksplisiete deurbreek van funksiebegrippe: onderskraag deur die wiskunde waarin die funksiebegrip ook 'n onmiskenbare plek gevind het. Die innerlike onhoudbaarheid van die Thomistiese substansiebegrip word in detail deur Ter Horst verduidelik (Ter Horst 2008).

Dooyeweerd wys tereg daarop dat die moderne fisika egter nie bloot vanuit' $n$ enkele funksie van die aard van individuele dinge as totaliteite rekenskap kan gee nie aangesien sulke dinge tegelyk in méér as een aspek funksioneer:

Modern physics now realizes that it cannot teach us what fills its modal functional schema $\mathrm{x}, \mathrm{y}, \mathrm{z},(\mathrm{ci}) \mathrm{t}$. It can only teach us how it is filled in the modal sense of the energy-aspect, though this 'how' implies the typical quantum-structure of energyoperation' [In Moderne Fisika is daar besef dat fisika ons nie kan leer waaruit sy modale funksionale skema $\mathrm{x}, \mathrm{y}, \mathrm{z},(\mathrm{ci}) \mathrm{t}$ bestaan nie. Dit kan ons slegs leer hoe dit saamgestel is in die modale sin van die energieaspek, hoewel hierdie 'hoe' die tipiese kwantum-struktuur van energieinteraksie impliseer].

(Dooyeweerd 1997-III:101)

Hoewel die Pythagoreërs skynbaar die moderne tyd in hierdie opsig vooruit was met hul stelling dat alles getal is, het dit vir hulle in laaste instansie om die wese van dinge gehandel. In sy betekenisvolle werk oor funksiebegrip en dingebegrip [Substanzbegriff und Funktionsbegriff] stel Cassirer treffend ondersoek in na die aard van funksiebegrippe as relasiebegrippe. Die uitlig van hierdie onderskeiding is 'n belangrike verdienste van die werk van Cassirer (Cassirer 1953:27). Wat Cassirer hier in gedagte het is inderdaad die klemverskuiwing van dingebegrippe na funksiebegrippe. Laasgenoemde is daarom alternatiewelik ook as relasiebegrippe aangedui. Rickert vind selfs in die relasiebegrippe wat deur die natuurwetenskappe gebruik word ' $\mathrm{n}$ aanknopingspunt vir sy bekende onderskeiding tussen generaliserende natuurwetenskappe en individualiserende (historiese) geesteswetenskappe (Rickert 1913:68-69, 173, 197).

Dit is juis hierdie erkenning van die gerelateerdheid van alles wat vanself die vraag na die aard van hierdie relasies of betrekkinge tussen werklikheidsgegewens oproep.

\section{Opmerking: Relasionele samehang}

Ons het Von Weizsäcker se siening aangehaal waarvolgens alles saamhang (gerelateerd is). Wanneer alle klem op funksiebegrippe (relasiebegrippe) geplaas word bestaan die gevaar dat die wetenskap die individuele konkreetheid van bestaande dinge, wat steeds die verwysingspunt van die dingbegrippe in ons alledaagse vervaring bly, in 'n funksionalistiese veralgemening sal elimineer. Sedert die Renaissance word die moderne (wysgerige en natuurwetenskaplike) denke tewens konsekwent gefunksionaliseer: dinge word opgelos in hul funksies of relasies. Hier kan ons allereers dink aan die hooftendens van die klassieke fisika wat daarop uit was om alle fisiese verskynsels tot matematies-kinematiese bewegings te herlei.

Dit vind ook ' $\mathrm{n}$ treffende uitdrukking in die logiese ideaal wat volgens Rickert natuurwetenskaplike arbeid moet begelei, naamlik om 'dingebegrippe so ver moontlik in relasiebegrippe' te transformeer. Rickert glo dat sy teorie geldig is vir die ideaal om in die natuurwetenskappe bloot nog met relasiebegrippe te opereer (Rickert 1913:68-70).

Die kwantum-teorie is ' $n$ voorbeeld van so ' $n$ universeelrelasionele (funksionele) perspektief, want as 'n teorie vir alle moontlik fisiese voorwerpe is dit nie ingeperk tot enkele groepe entiteite nie. Von Weizsäcker skryf tereg: 'Wanneer die kwantum-teorie toereikend abstrak geformuleer word, is dit ' $n$ universele teorie vir alle klasse entiteite'(Von Weizsäcker 1993:128).

Om Einstein se aanname van $c$ as konstante te waardeer word by wyse van kontrastering aandag geskenk aan die aard van die historisme en die verskil tussen relatiwiteit en relativisme.

\section{Historisme en relatiwiteit}

Die 18de eeu was nog in die greep van die rasionalisme van hierdie era, in die waan dat niks aan die universele appèl van begripsvorming kan ontkom nie. Aan die begin van die 19de eeu sien ons egter ' $n$ wending na dít wat uniek en individueel is: wat tegelyk die oorgang van die rasionalisme na die irrasionalisme belig. Hierdie wending hang saam met die opkoms van die Romantiek en die daarmee gepaardgaande historisme wat veranderlikheid sentraal stel. Johann Herder word deur Cassirer as die Kopernikus van die geskiedeniswetenskap gesien (Cassirer 1957:226 e.v.), terwyl Niebuhr veranderlikheid beklemtoon het met verwysing na die Plato se allegorie van die grot-bewoners: die historikus hou hom met die skadubeelde onder die grond besig, met verandering as die sentrale tema (sien Cassirer 1957:235 e.v.). Meinecke beskryf Goethe se nuwe wetsbegrip treffend wanneer hy beklemtoon dat dit totaal verskillend van die Verligting se wetsbegrip is aangesien dit volledig bevry is van alle wiskundige bestanddele (Meinecke 1965:504).

Sedert 1815 is hierdie nuwe historistiese instelling verder gevoer deur Von Savigny waarvolgens alles opgeneem word in die ewigdurende opkom, blink en versink van (historiese) gebeure: alles is geskiedenis. As alles egter geskiedenis is, is daar niks (nie-histories) oor wat 'n geskiedenis kan hê nie. Dan sal ons van 'n geskiedenis van die geskiedenis moet praat, wat 'n kontradiksie in terme is. Slegs dít wat nie geskiedenis is nie, kan 'n geskiedenis hê. Om van iets soos regsgeskiedenis, ekonomiese geskiedenis of kunsgeskiedenis te praat veronderstel dat ons hier met veranderinge op die basis van duursaamheid te doen het. Dit sal andersins onmoontlik wees om byvoorbeeld na die Romeinse Reg of die RomeinsHollandse Reg te verwys, want dan moet die regsaspek van ons ervaringsrealiteit êrens in die verlede 'plaasgevind' het, 
soos die val van die Romeinse Ryk of the Slag van Waterloo. Dan is reg, net soos die Slag van Waterloo, verby en behoort tot die vergange verlede. Slegs indien egter van die regsaspek as konstante basis uitgegaan word is dit moontlik om van 'n regsgeskiedenis te praat. Hans Jonas (1974) verwys daarom tereg na hierdie element van konstansie as transhistories:

For history itself no less than historiography is possible only in conjunction with a transhistoric element. To deny the transhistorical is to deny the historical as well [Want geskiedenis, net soos historiografie, is slegs moontlik in verbondenheid met ' $n$ transhistoriese element. Deur die transhistoriese te misken, word ook die historiese misken.]

(Jonas 1974:242)

Die ironie van die historisme is dus dat indien alles geskiedenis is, daar inderdaat niks oor is wat 'n geskiedenis kan hê nie!

Hoewel die begin van die 20ste eeu reeds duidelike oorgangstekens na die sogenaamde taalwending toon, bly die historisme die dominerende ondertoon, tot so ' $\mathrm{n}$ mate dat Einstein nie aan die 'tydsgees'-effek daarvan sou ontsnap nie. Ons ondersoek egter eers die Lorentz transformasie waarvan Einstein gebruik gemaak het.

\section{Resultate}

\section{Die sleutelrol van die snelheid van lig}

In die meganika van Newton word die oorgang van een inersiële sisteem tot ' $n$ ander een deur Galilei se transformasie bemiddel, waarin snelhede eenvoudig regstreeks (aritmeties) opgetel word. Dit sou egter blyk dat optelling ook in niearitmetiese kontekste aangetref word. In die geval van vektore, wat oor afstand en rigting beskik, is $2+2$ byvoorbeeld nie noodwendig gelyk aan 4 nie. Veronderstel 'n persoon beweeg eers $2 \mathrm{~km}$ noordwaarts en daarna $2 \mathrm{~km}$ ooswaarts, dan sal daardie persoon $\sqrt{8} \mathrm{~km}$ van die vertrekpunt wees; in hierdie geval (van ruimtelike optelling) is $2+2=\sqrt{8}$. (Die streep bo ' 2 ' dui aan dat dit gaan oor ruimtelike optelling en nie oor getalsoptelling nie.)

Met sy kontraksie-faktor het Lorentz gestalte gegee aan bewegingsoptelling.

$\frac{1}{\sqrt{1-v^{2} / c^{2}}}$

[Verg. 2]

In sy spesiale relatiwiteitsteorie van 1905 het Einstein die vakuum-snelheid van lig as konstant aanvaar en wel deur te postuleer dat geen fisiese entiteite vinniger as lig kan beweeg nie. Hy wys daarop dat die snelhede van fisiese liggame nie die snelheid van lig kan oortref nie: 'n postulaat wat regstreeks volg uit die waarde van $\sqrt{1}-v^{2}$ in die spesiale Lorentz transformasie (Einstein 1982:41 nota 2).

Veronderstel twee deeltjies beweeg in teenoorgestelde rigtings, elk teen 'n snelheid van $0.9 c$. In terme van Galilei se transformasie sal die snelheid waarmee hierdie deeltjies van mekaar wegbeweeg dus 1.80 c wees, in stryd met Einstein se postulaat. Word die Lorentz transformasie daarenteen toegepas, blyk dit dat die gemelde twee entiteite van mekaar teen ' $\mathrm{n}$ snelheid wat kleiner as $c$ is wegbeweeg, naamlik $1.80 c<c$

1.81

Einstein was volkome bewus van die beperkinge van die klassieke meganika wat alle fisiese verskynsels tot die beweging van al of nie gelade massapunte wou teruggevoer. In die loop van die 19de eeu sou dit egter blyk dat ter onderskeiding van 'n suiwer kinematiese perspektief waar alle prosesse omkeerbaar is, fisiese prossesse onomkeerbaar is. Einstein verduidelik dat daar 'termodinamiese prosesse bestaan wat "onomkeerbaar" is', ter onderskeiding van die perspektief van 'n '"molekulêr-meganiese oogpunt van waaruit alle prosesse omkeerbaar is"' (Einstein 1959:42). Einstein bevestig hiermee dat die kinematiese aspek van eenparige (konstante) beweging en die fisiese aspek van energie-werking (verandering) onherleibaar is. Hy meld ook Heinrich Hertz as die laaste voorstander van die reduksie van (onomkeerbare) fisiese verskynsele tot omkeerbare (kinematiese) prosesse: Hertz wou die fisiese aspek as verklaringsbeginsel elimineer deur die kragberip (potensiële energie) daarin te ontken (Einstein 1959:30).

Gevolglik wys Einstein (en ook Max Planck) die meganistiese reduksie van die klassieke fisika af. Einstein openbaar ' $n$ negatiewe houding jeens the mechanistic framework of classical physics' [Die meganistiese raamwerk van Klassieke Fisika] (Einstein 1985:146). Planck skryf dat die meganiese natuuropvatting die beskouing is 'waarvolgens alle fisiese prosesse in die natuur volledig tot die bewegings van onveranderlike, gelyksoortige massapunte of massaelemente teruggevoer kan word' (Planck 1910:53).

Dit is merkwaardig dat die Duitse fisikus, Carl Friedrich Von Weizsäcker, steeds glo dat beweging en snelheid nog altyd beskou moet word as basiese begrippe van alle suiwer wetenskap (Von Weizsäcker 2002:196, voetnoot). Hiermee gaan hy voort met ' $n$ tradisie wat teruggevoer kan word tot by Galilei aangesien ons natuurwetenskaplike denke volgens laasgenoemde slegs getalseienskappe (telbaarheid), ruimtelike eienskappe (vorm, grootte, plek en kontak), en kinematiese eienskappe (beweging) benodig (Hucklenbroich 1980:291).

Sonder die Lorentz transformasie was Einstein gekonfronteer met die onhoudbaarheid van die poging om beide die aansprake wat in hierdie volgende stellings opgesluit lê, te versoen:

- die konstantheid van die snelheid van lig

- die onafhanklikheid van die wette (derhalwe in besonder ook die Wet van Konstante Ligsnelheid) van die keuse van ' $n$ inersiële sisteem (die spesiale relatiwiteitsbeginsel).

Hoewel elkeen van hierdie stellings op sigself genome, deur ervaring onderskryf word, is hulle wederkerig uitsluitend in terme van die verbindingsreëls met behulp waarvan die Klassieke Fisika ruimtelike koördinate en die tyd van gebeurtenisse by die oorgang van een inersiële sisteem tot ' $n$ 
ander een hanteer. Eers wanneer die Lorentz transformasie benut word is dit moontlik om hierdie onversoenbaarheid op te hef (Einstein 1959:54, 56).

Einstein gebruik in hierdie verband die volgende twee terme afwisselend: konstansie en invariansie (Einstein 1959:56, 66). Beide appelleer op die aard van uniformiteit (orde van konstansie of invariansie) wat in die kinematiese aspek aangetref word. Bryon en Spielberg beklemtoon tereg dat Einstein se spesiale relatiwiteitsteorie gemoeid is met 'invariansie', maar ongelukkig word dit verwar met die terme absoluut en onveranderlik (Bryon \& Spielberg 1987:6). Daarom is dit geen verrassing dat Einstein geensins in 'willekeurige konstantes' geïnteresseerd was nie, want hy merk op 'dat daar in hierdie wette slegs rasioneel volledig-bepaalde konstantes optree (en derhalwe nie konstantes waarvan die getalswaardes verander kan word nie)' (Einstein 1959:62). Hy merk verder op dat Lorentz se transformasie en sy invariansie-teorie die basis vorm van die ganse invariansieteorie van die spesiale relatiwiteitsteorie (Einstein 1982:39).

Hieruit blyk dit duidelik dat die spesiale relatiwiteitsteorie na sy aard 'n kinematiese teorie is en dat die orde van konstansie deurslaggewend daarin is. Dit onderlê die sleutel-postulaat van die spesiale relatiwiteitsteorie: die konstansie van die snelheid van lig (c). In Duits word dit soms kernagtig en meer spesifiek gestel: 'die konstantheid van die snelheid van lig in 'n vakuum' (Einstein 1959:54; Einstein 1982:30-31).

Einstein was egter nie skuldig aan die klassieke meganistiese reduksie van fisiese verskynsels tot kinematiese gegewens nie. Hy merk tewens op dat die vergelykings van die meganika (soos die traagheidswet) slegs daarop aanspraak maak dat dit geldig is ten opsigte van ' $n$ besondere klas van sisteme, naamlik 'inersiële sisteme' (Einstein 1959:26). Daarom het hy later die algemene relatiwiteitsteorie ontwikkel waarin die fisiese aspek ingesluit word. Dit wat gesê word van liggame wat teen 'n konstante snelheid beweeg in die spesiale relatiwiteitsteorie, is in die algemene relatiwiteitsteorie ook geldig ten opsigte van liggame wat aan versnelling onderworpe is (gravitasie kan nie van versnelling onderskei word nie). Newton se gravitasiewet is soms ook as die lae swaartekrag-grens van Einstein se algemene relatiwiteitsteorie aangedui, omdat Einstein se algemene relatiwiteitsteorie Newton se gravitasie herlei tot die grensgeval van klein potensiaal en lae snelhede (Burchell 2011).

In die loop van die 19de eeu het meer gevorderde waarnemings die beperkinge van berekeninge uitgewys wat met behulp van Newton se teorie gedoen is en dit het geblyk dat berekeninge wat van Einstein se algemene relatiwiteitsteorie gebruik maak nader ooreenstem met die waarnemings van sterrekundiges.

Beskou nou egter ' $n$ bewegende inersiële sisteem $K$ waarin vanaf 'n punt $P_{1}$ 'n ligstraal na 'n punt $P_{2}$ in 'n leë ruimte beweeg, met $r$ as die afstand wat tussen die twee punte gemeet is. Dan sal die voortplanting van die ligstraal die vergelyking $r=c \cdot \Delta t$ bevredig. Indien hierdie vergelyking gekwadreer word en $r^{2}$ uitgedruk word as die koördinaatverskil $\Delta x_{y^{\prime}}$ kan die vergelyking ook geskryf word as:

$\sum\left(\Delta x_{\mathrm{y}}\right)^{2}-c^{2} \Delta t^{2}=0$

[Verg. 3]

Hierdie vergelyking beliggaam dan volgens Einstein die 'beginsel van die konstansie van die snelheid van lig met betrekking tot $K^{\prime}$. Hierby voeg hy die volgende belangrike opmerking: hierdie beginsel geld 'onafhanklik van die bewegingstoestand van die ligbron wat die ligstraal uitgestuur het' (Einstein 1982:32).

Uiteraard het die relatiwiteitsteorie van Einstein aangetoon hoedanig die aard van die oorspronklike sin van ruimtelike gelyktydigheid deur die beweging van 'n sisteem gerelativeer word. Selfs die begrip 'rus' is nie meer in die fisika sinoniem met statiese ruimtelikheid nie. In 'n brief aan Moritz Schlick (07 Junie 1920) skryf Einstein: 'Rest is a dynamic event in which the velocities are constantly zero, one that for our consideration is, in principle, equivalent to any other event or motion' [Rus is ' $n$ dinamiese gebeurtenis waarin die snelhede konstant zero is; ' $n$ toestand wat vir ons doeleindes in beginsel dieselfde is as enige ander gebeurlikheid of beweging] (Einstein 2006:186). Gevolglik handhaaf Einstein dat nòg die ruimtelike punt waarin iets gebeur, nòg die tydstip waarop dit gebeur, fisiese realiteit besit. Fisiese realiteit kom slegs aan die gebeurtenis sélf toe (Einstein 1982:33).

Dit gaan uiteindelik oor fisiese ruimte wat van matematiese ruimte verskil. Sedert Descartes glo die moderne filosofie tewens dat alles in die natuur ' $\mathrm{n}$ gapinglose kontinuïteit vertoon, want die natuur maak geen spronge nie (natura non facit saltus). Hoewel die 17de eeuse filosoofwiskundige, Leibniz, begin met diskrete monade ontvang die kontinuïteitswet (lex continui) die voorrang in sy denke (Leibniz 1976:397). Die klassieke wetenskapsideaal van die moderne wysgerige denke is oortuig dat alle gapings of diskontinuitteite teoreties oorbrug kan word, selfs al benodig dit die idee van oneindig-klein oorgange. Die bekende bioloog Linaeus, asook Darwin self, was in die greep van 'n a priori geloof in hierdie stelling dat die natuur geen spronge maak nie; Darwin gebruik die uitdrukking verskeie kere in sy Origin of Species (Darwin 1859b: 116, 124, 307): 'Natural selection acts only by the preservation and accumulation of (infinitesimally [Darwin, 1859a:142]) small inherited modifications' [Natuurlike seleksie vind slegs plaas deur die bewaring en akkumulering van oneindig-klein oorgeêrfde modifikasies] (Darwin 1859b:56).

Die opvatting dat fisiese ruimte beide kontinu en oneindigverdeelbaar is, soos reeds aangetref by Griekse denkers soos Anaksagoras en Aristoteles, is aan die einde van die 19de en aan die begin van die 20ste eeu gewysig deur die ontdekking van Planck se kwantum-van-werking. Hoewel beide matematiese ruimte en fisiese ruimte uitgebreid is, is eersgenoemde dus kontinu en oneindig-verdeelbaar terwyl laasgenoemde, gebonde aan die kwantum-struktuur van energie, nòg kontinu, nòg oneindig-verdeelbaar is (Hilbert 
1925:164). Einstein se algemene relatiwiteitsteorie het hieraan die perspektief van die 'gekromde wêreld-ruimte' toegevoeg, wat tot sy bekende opvatting gelei het waarvolgens die heelal onbegrens maar tog eindig is (Einstein 1985:108 e.v.).

\section{Tussen konstansie en historisme: Het Einstein 'n relatiwiteitsteorie ontwikkel?}

Einstein het eers in 1907 die uitdrukking relatiwiteitsteorie gebruik, wat voorafgegaan is deur ' $\mathrm{n}$ voordrag van Max Planck in 1906 waarin hy van die 'Relativtheorie' [Relativiteitsteorie] praat (Einstein 1907; Planck 1906).

Ons het hierbo gesien dat Einstein die terme konstansie en invariansie afwisselend gebruik heten dathy nie geïnteresseerd was in ' $\mathrm{n}$ konstante waarvan die getalswaardes verander kan word nie. Die deurslaggewende veronderstelling van die spesiale relatiwiteitsteorie, as ' $\mathrm{n}$ suiwer kinematiese teorie, is gegee in die aanname dat die vakuum-snelheid van lig konstant is. Die beweging van enige inersiële sisteem is altyd relatief tot hierdie konstante ligsnelheid.

Op hierdie punt ontmoet ons die onvermydelike teenwoordigheid van ongedefinieerde of primitiewe terme in die fisika. Rasionele begripsdenke berus in laaste instansie altyd op ongedefinieerde primitiewe terme wat onherroeplik op die onselfgenoegsaamheid van alle teoretiese denke dui: 'n mens kan slegs iets begryp met behulp van terme wat sélf nie in begrip vervat is nie. Die keersy van dergelike primitiewe terme is in die onverbreeklike samehang daarvan met ander primitiewe terme gegee. Yourgrau vewys na Gödel wat gevolglik volgehou het 'that to know the primitive concepts, one must not only understand their relationships to the other primitives but must grasp them on their own, by a kind of "intuition"' [om die primitiewe konsepte te verstaan, moet " $n$ mens nie slegs hulle verwantskap met ander primitiewe konsepte verstaan nie, maar elkeen individueel verstaan deur middel van ' $n$ tipe "intuïsie".] (Yourgrau 2005:169).

Ons het reeds opgemerk dat die sleutel-term konstansie (konstantheid) verband hou met die aard van 'n kinematiese subjek, 'n eenparige of konstante beweging. Dit beliggaam ons basiese kinematiese intuïsie, wat gefundeer is in ons getalsintuïsie (beweging-snelheid, aangedui deur 'n getal) en ons ruimte-intuïsie (bewegings-baan). Die term krag is ontleen aan ons fisiese intuïsie en dit kan nie tot getal, ruimte of beweging herlei word nie. Gesamentlik vorm hierdie vier verklaringswyses of verklaringsmodi die raamwerk waarbinne fisiese teorieë gestalte aanneem, soos ons vroeër reeds verduidelik het aan die hand van die elemente van Newton se gravitasiewet.

Indien ons vir 'n oomblik sou afsien van die naam waaronder Einstein se (spesiale en algemene) teorie bekend is, naamlik dat dit 'n relatiwiteitsteorie is, en bloot sou let op die sleutelaannames daarvan, is die dominant-opvallende kern-element ongetwyfeld gegee in die postulaat rakende $c$, die konstante snelheid van lig in 'n vakuum. Nie alleen verteenwoordig dit die boonste grens van snelhede wat fisiese liggame kan behaal nie, maar dit stel tegelykertyd ' $n$ maatstaf daar waaraan bewegende liggame gemeet kan word. Wanneer
Grünbaum Einstein se 'principle of the constancy of the speed of light' [beginsel van die konstantheid van die snelheid van lig] bespreek, wys hy daarop dat dit ' $n$ boonste grens behaal wat slegs in ' $\mathrm{n}$ vakuum gerealiseer kan word (Grünbaum 1974:376). Wat merkwaardig is, is dat Einstein se teorie van die standpunt uitgaan dat die hipotese dat 'n enkele lig sinjaal 'n konstante snelheid besit ten opsigte van alle moontlike bewegende sisteme, sonder dat noodwendig vereis word dat so 'n sinjaal werklik bestaan (Grünbaum 1974:377). Stafleu merk gevolglik op: 'The empirically established fact that the velocity of light satisfies the hypothesis is comparatively irrelevant' [Die empiries-bevestigde feit dat die snelheid van lig die hipotese bevredig is min of meer irrelevant] (Stafleu 1980:89). Hierdie gegewe hou verband met die modale universaliteit van die fisiese aspek, naamlik dat alle bewegende sisteme, ongeag die tipiese aard daarvan, in die kinematiese aspek funksioneer. Heidegger is daarom geregverdig in sy bevestiging (1924) dat die invariansie (konstansie!) van Einstein se vergelykings met betrekking tot willekeurige transformasies die positiewe kant van sy teorie verteenwoordig (Heidegger 1992:3).

Eers wanneer dit duidelik genoeg geword het dat die kern van Einstein se relatiwiteitsteorie in die aard van konstansie gegee is, kan tot die slotsom gekom word dat sy teorie in die eerste plek eintlik as ' $n$ teorie van konstansie (konstantheid) waardeer behoort te word. Die uiteindelike algemene verbreidheid van die term relatiwiteitsteorie suggereer egter dat hierdie ingeburgerde naamgewing die invloed van die historisme verraai want, soos ons vlugtig hierbo aangetoon het, het Einstein sy teorie die lig laat sien in ' $n$ tyd waarin die historistiese relativering van alles nog duidelik sy invloed laat geld het. Dit wil dus voorkom asof Einstein 'n toegif aan die tydsgees gemaak het deur sy teorie nie in die eerste plek as ' $n$ teorie van konstansie bekend te stel nie.

Hoewel sy teorie die weg van relasiebegrippe (funksiebegrippe) gevolg het, gegewe dat die spesiale en algemene teorieë onderskeidelik modaal-kinematiese en modaal-fisiese gesigspunte ontgin, het hyself nogtans allermins in die fomulering van sy teorie in enige historistiese slaggat vasgeval. Waar Einstein van relatiwiteit praat geskied dit $o p$ die basis van konstansie. Daarteenoor is dit juis die bedoeling van die historisme om veranderlikheid te beklemtoon ten kostevan konstansie. Die gevolg hiervan is dat Einstein se teorie nie deur die innerlik-teenstrydige aard van die historisme geaffekteer is nie. Vergelyk hierby Clouser se kritiese ontleding van die vier hoof stellinge wat Rorty ontwikkel in sy pragmatistiese ondersteuning van die strekking van die historisme, te wete 'the ubiquity of language, the non-correspondence thesis, and historicism' [die alomteenwoordigheid van die taal, die niekorresponderende stelling, en historisme] (sien Rorty 1982 en 1996). Hy toon aan dat 'far from mutually supporting one another, these theses are related in such a way that if any one is true the others can't be' [sonder om mekaar wedersyds te ondersteun, hou hierdie stellings op so manier met mekaar verband dat die een nie waar kan wees as die ander is nie] (Clouser 2005b:18). Sy finale oordeel lui soos volg:

Therefore I find that Rorty has failed to rescue historicism from the incoherencies native to it. Its central claims are still self-referentially, self-assumptively, and self-performatively incoherent, and Rorty's additions to them only compound 
the difficulties by being mutually inconsistent. [Daarom vind ek dat Rorty nie daarin kon slag om historisme te red van die onsamehangendhede eie daaraan nie. Historisme se sentrale eise is steeds self-verwysend, -verondersteld en -uitvoerbaar onsamehangend. Rorty se byvoegings vererger net die probleme deur wedersydse teenstrydigheid.]

(Clouser 2005b:19)

Die funderende samehang tussen die kinematiese en fisiese aspekte verklaar tewens waarom verandering ('n fisiese gegewe) slegs vasgestel kan word op die basis van konstansie ('n kinematiese gegewe). Vergelyk hierby ook die opmerkinge uit die protofisika van Peter Janich oor hierdie funderende rol van die kinematiese aspek ten opsigte van die fisiese aspek. Hy verbind die onderskeiding tussen die kinematiese en die fisiese aan die gegewe dat die moderne fisika ' $n$ dinamiese interpretasie aan die stelling heg dat 'n liggaam sy snelheid slegs kontinu kan verander. Wanneer bepaalde kondisies aanwesig is kan 'n liggaam nooit diskontinu versnel nie omdat dit ' $n$ verandering sal verg wat oneindig groot is, wat op sy beurt ' $\mathrm{n}$ krag sal benodig wat oneindig groot is (Janich 1975:68-69).

\section{Gevolgtrekkinge}

$\mathrm{Na}$ alles het Einstein derhalwe in die eerste instansie nie 'n relatiwiteitsteorie nie, maar 'n 'konstansie-teorie' ontwikkel en daarmee terselfdertyd 'n natuurwetenskaplike bevestiging gegee van wat Plato (soos vroeër hierbo vermeld) reeds ingesien het, naamlik dat as alles verander geen kennis moontlik sal wees nie. In sy dialoog Kratylos (439c-440a) redeneer Plato immers dat die 'eie wese' van dinge 'n houvas vir kennis bied omdat dit altyd dieselfde bly (dit is sy beroemde leer van bo-sintuiglike, ewige, statiese ideë).

Terselfdertyd het Einstein ook implisiet besef dat relatiwiteit nie relativisme is nie, want laasgenoemde (soos dit tewens ook in die postmodernisme na vore tree) beklemtoon verandering ten koste van duursaamheid (konstansie). Sonder die konstante ligsnelheid $c$ verval Einstein se spesiale relatiwiteitsteorie in nikseggendheid, want alle beweging is daarvolgens relatief met betrekking tot hierdie konstante $c$.

\section{Literatuurverwysings}

Arp, H., Baryshev, Y., Brynjolfsson, A., Bondi, H., Eastman, T. \& Gallo, C., 2004, An Open Letter to the Scientific Community cosmologystatement.org ['n Ope brief aan die Wetenskap Gemeenskap cosmologystatement.org], viewed 06 May 2010, from http://www.cosmologystatement.org/

Bryon, D.A. \& Spielberg, N., 1987, Seven ideas that shook the universe [Sewe idees wat die heelal geruk het], John Wiley \& Sons, New York.

Burchell, B., 2011, Alternative Physics. Where science makes sense [Alternatiewe Fisika. Waar die wetenskap sin maak], viewed 14 April 2011 from, http://www. alternativephysics.org/book/GeneralRelativity.htm

Cassirer, E., 1957, Das Erkenntnisproblem in der Philosophie und Wissenschaft der neueren Zeit [Kennisprobleme in Filosofie en Wetenskap in die moderne tyd] Kohlhammer Verlag, Stuttgart.

Cassirer, E., 1953, Substance and function [Substansie en funksie], 1st English edn. of the original version, Substanzbegriff und Funktionsbegriff, Dover, New York.

Clouser, R.A., 2005a, The myth of religious neutrality: An essay on the hidden role of religious belief in theories [Die mite van religieuse-neutraliteit: ' $n$ Geskrif oor die versteekte rol van religieuse-oortuiging in teorieë], new rev. version, University of Notre Dame Press, Notre Dame.

Clouser, R., 2005b, 'A critique of historicism' ['n Beoordeling van historisme], Acta

Darwin, C., 1859a, On the Origin of Species by Means of Natural Selection or the Preservation of favoured races in the struggle for life [Oor die Oorsprong van Soorte deur middel van Natuurlike Seleksie of die bewaring van begunstigde rasse in die Stryd om Oorlewing], edited with an introduction by J.W. Burrow, Penguin Books, Hardmondsworth.
Darwin, C., 1859b, On the Origin of Species by Means of Natural Selection or the Preservation of favoured races in the struggle for life, [Oor die Oorsprong van Soorte deur middel van Natuurlike Seleksie of die bewaring van begunstigde rasse in die Stryd om Oorlewingl, viewed 29 October 2005 from, http://www.infidels. org/library/historical/charles_darwin/origin_of_species/Intro.html

Descartes, R., 1965, A discourse on method, Meditations and principles ['n Dialoog oor metode, Meditasies en beginsels], transl. John Veitch, Everyman's Library, London.

Dooyeweerd, H., 1997, A new critique of theoretical thought ['n Nuwe beoordeling van teoretiese denke], Collected works of Herman Dooyeweerd, A Series vols. I-IV, van teoretiese denke], Collected works of Herm
ed. D.F.M. Strauss, Edwin Mellen, Lewiston.

Einstein, A., 1985, Relativity, the special and general theory [Relatiwiteit, die spesiale en die algemene teorie], Arrowsmith, Bristol.

Einstein, A., 1982, Grundzüge der Relativitätstheorie [Grondbeginsels van die relatiwiteitsteorie], Friedrich Fieweg \& Sohn, Wiesbaden.

Einstein, A., 1959, 'Autobiographical Notes'[Outobiografiese Notas], in P.A. Schilpp (ed.), Albert Einstein, Philosopher-Scientist, pp. 1-94, Harper Torchbooks, New York.

Einstein, A., 1907, 'Über die vom Relativitätsprinzip geforderte Trägheit der Energie' [Aangaande die traagheid van energie wat deur die relatiwiteitsbeginsel vereis word], Annalen Physik 23, 371-384.

Grünbaum, A., 1974, Philosophical problems of space and time [Filosofiese probleme met ruimte en tyd], 2nd enlarged edn., D. Reidel, Dordrecht.

Hawking, S. \& Miodinow, L., 2010, The Grand Design [Die Grootse Ontwerp], viewed 16 November 2010 from, http://weeklyworldnews.com/headlines/21829/ 16 November 2010 from, http://weeklyworld

Heidegger, M., 1992, The concept of time [Die konsep van tyd], Blackwell, Oxford.

Hilbert, D. 1925, 'Über das Unendliche' [Aangaande die Oneindigheid], Mathematische Annalen, vol. 95, 161-190. doi:10.1007/BF01206605

Hucklenbroich, P., 1980, 'Der physikalische Begriff der Materie'[Die fisiese konsep van materie], in J. Ritter, K.F. Gründer \& G. Gabriel (eds.), Historisches Wörterbuch der Philosophie, vol. 5, pp.921-924, Schwabe \& Co Verlag, Stuttgart.

Janich, P., 1975, 'Tragheitsgesetz und Inertialsysteem' [Traagheidswet en traagheidsisteem], in Chr. Tiel (Hrsg.), Frege und die moderne Grundlagenforschung n.p., Hain, Meisenheim am Glan.

Jonas, H., 1974, Philosophical essays: from ancient creed to technological man [Filosofiese verhandelinge: van antieke geloof tot tegnologiese mens], PrenticeHall, INC., Englewood Cliffs, New Jersey.

Leibniz, G.W.L., 1976, Philosophical papers [Filosofiese artikels] in L.E. Loemker (ed.), Synthese Historical Library, vol. 2, D. Reidel, Dordrecht-Holland.

Maier, A., 1949, Die Vorläufer Galileis im 14. Jahrhundert [Die pionier Galilei in die veertiende eeu], Edizioni di Storia e letteratura, Roma.

McKeon, R. (ed.), 2001, The basic works of Aristotle [Die basiese werke van Aristoteles] introduction by C.D.C. Reeve, The Modern Library, New York.

Meinecke, F., 1965, Die Entstehung des Historismus [Die opkoms van historisme], Werke Volume III, Hrsg. C. Hinrichs, R. Oldenburg Uitgever, München.

Planck, M., 1973, Vorträge und Erinnerungen [Lesings en punte om te onthou], Nachdruck der 5. Auflage, 1949; 9, unveränderte Auflage 1965, Wissenschaftliche Buchgesellschaft, Darmstadt.

Planck, M., 1915, Das Prinzip der kleinsten Wirkung, Kultur der Gegenwart [Die beginsel van minimum aksie, hedendaagse kultuur], B.G. Teubner, Leipzig.

Planck, M., 1910, 'Die Stellung der neueren Physik zur mechanischen Naturanschauung' [Die stellingname van die Moderne Fisika ten opsigte van die meganiese natuurbeskouing], Vortrag, gehalten am 23 September 1910 auf de 82. Versammlung Deutscher Naturforscher und Ärzte in Königsberg.

Planck, M., 1906, 'Die Kaufmannschen Messungen der Ablenkbarkeit der ß-Strahlen in ihrer Bedeutung für die Dynamik der Elektronen' [Die Kaufmann-metings van die verstrooiing van $ß$-strale en die belangrikheid daarvan vir die dinamika van elektrone], Physikalische Zeitschrift 7, 753-761.

Plato, 1973, The Collected Dialogues of Plato. Including the Letters, E. Hamilton \& C. Huntington (eds.), University Press, Princeton.

Rickert, H., 1902, Die Grenzen der naturwissenschaftlichen Begriffsbildung [Die grense van wetenskaplike konsepvorming], Mohr, Tübingen.

Rorty, R., 1996, 'Relativism: Finding and Making' [Relativisme: Om dit te skep en daar te stel], in J. Niznik \& T. Sanders (eds.), Debating the State of Philosophy, pp. 3147, Praeger, Westport, CT.

Rorty, R., 1982, Consequences of Pragmatism [Die gevolge van Pragmatisme] Minnesota,University of Minnesota Press, University of Minnesota.

Stegmüller, W., 1987, Hauptströmungen der Gegenwartsphilosophie [Hoofstrome van Kontemporêre Filosofie], Volume III, Alfred Kröner Verlag, Stuttgart.

Strauss, D.F.M., 2009, Philosophy: discipline of the disciplines [Filosofie: disipline van die disiplines], Paideia Press, Grand Rapids.

Ter Horst, G., 2008, De ontbinding van de substantie. Een deconstructie van de beginselen van vorm en materie in de ontologie en de kenleer van Thomas van Aquino [Die ontbinding van die substansie: 'n Dekonstruksie van die beginsels van vorm en materie in die ontologie en die epistemologie van Thomas Aquinas], Uitgevrij Eburon, Delft.

The Economist, 2010, 'Understanding the universe. Order of creation. Even Stephen Hawking doesn't quite manage to explain why we are here' [Om die heelal te verklaar waarom ons bestaan nie], The Economist, viewed 09 September 2010 from, http://www.economist.com/node/16990802

Von Weiszäcker , C.F., 2002, Große Physiker, Von Aristoteles bis Werner Heisenberg [Grootse fisici, Van Aristoteles tot Werner Heisenberg], Deutscher Taschenbuch Verlag, München.

Von Weiszäcker, C.F., 1993, Der Mensch in seiner Geschichte [Die Mens en sy geskiedenis], DTV, München.

Yourgrau, P., 2005, A world without time. The forgotten legacy of Gödel and Einstein ['n Wereld sonder tyd. Die vergete nalatenskap van Gödel en Einstein], Penguin Books, London. 